\title{
PENGARUH KINERJA PELAYANAN JASA BARANG TERHADAP JASA KAPAL
}

\author{
Atik Devi Lestari' ${ }^{1}$, Winoto Hadi $^{2}$ \\ Atik Devi Lestari', Winoto Hadi
Email : atikdevi1@ gmail.com $^{1}$, winoto@unj.ac.id $^{2}$ \\ 1'Prodi D III Transportasi, Fakultas Teknik - Universitas Negeri Jakarta \\ Prodi D III Transportasi, Fakultas Teknik - Universitas Negeri Jakarta
}

\begin{abstract}
Abstrak. Kegiatan penelitian tugas akhir dilakukan selama melakukan kegiatan praktek kerja lapangan di PT Pelabuhan Indonesia II (Persero) Cabang Tanjung Priok. Penelitian ini bertujuan untuk mengetahui seberapa pengaruh kinerja pelayanan jasa barang terhadap pelayanan jasa kapal, sekaligus sebagai syarat kelulusan Prodi D3 Transportasi Universitas Negeri Jakarta. Untuk menyusun tugas akhir ini penulis mengunakan data sekunder yang berupa data Kinerja Operasi pada tahun 2018. Data yang didapatkan tersebut kemudian diolah oleh penulis menggunakan Metode Kuantitaf serta menggunakan rumus Uji T. Hasil dari ouput data yang keluar tersebut didapatkan dari uji $\mathrm{T}$ bahwa hubungan antara variabel curah cair $(\mathrm{X})$ dengan variabel effective time $(\mathrm{Y})$ ternyata positif dan signifikan.
\end{abstract}

Kata kunci: Kinerja, Pengaruh, Kapal, dan Barang

\begin{abstract}
Abstrac. Final assignment research activities are carried out during fieldwork activities at PT Pelabuhan Indonesia II (Persero) Tanjung Priok Branch. This study aims to determine how much influence the performance of goods services on ship services, as well as the graduation requirements for D3 Transportation Study Program, Jakarta State University. To compile this thesis the author uses secondary data in the form of Operational Performance data in 2018. The data obtained is then processed by the author using the Quantitative Method and using T test formula. The results of the data output that came out were found that $T$ test that relationship between the liquid bulk variable $(X)$ with the effective time variable $(Y)$ was positif and not significant.
\end{abstract}

Keyword: performance, influence, vessel, and goods

\section{A. PENDAHULUAN}

Perdagang merupakan salah satu faktor penting bagi pertumbuhan ekonomi dan pemasukan devisa bagi suatu negara. Indonesia sendiri merupakan negara maritim dimana $40 \%$ perdagangan logistik dunia melewati perairan di indonesia. Aktivitas perdagang di dalam negeri pun di lakukan hampir $70 \%$ melalui jalur laut. Sehingga peran dari pelabuhan dalam mendukung pertumbuhan ekonomi, perdagangan dan mobilitas ini sangat besar.

Dengan demikian berbagai upaya pengembangan dan perbaikan di sektor transportasi laut terus dilakukan dengan harapan pelabuhan - pelabuhan di Indonesia mempunyai daya saing yang tinggi, transparan, efektif, dan dapat meningkatkan efisiensi yang akan berdampak pada biaya logistik waktu penerimaan dan pengiriman kontainer. Upaya upaya ini tentu saja dilakukan bukan hanya dari pihak pemerintah namun juga dilakukan bagi si penyedia jasa yang memangku kepentingan dalam sektor kepelabuhanan itu sendiri.

Tidak terkecuali upaya pengembangan dan perbaikan yang dilakukan oleh PT Pelabuhan Cabang Tanjung Priok. PT Pelabuhan Indonesia II (Persero) Cabang Tanjung Priok sendiri adalah salah satu dari 12 Cabang yang dimiliki oleh PT Pelabuhan Indonesia II(Persero). Karena terletak di Jakarta menjadikan pelabuhan ini salah satu pelabuhan tersibuk di Indonesia. Lingkup pelyanan yang dilayani PT Pelabuhan Cabang Tanjung Priok yaitu pelayanan jasa bongkar dan muat petikemas domestik dan internasional, pelayanan batal muat dan alih kapal, pelayanan (DG) dangerous goods, Pelayanan Jasa pelayanan reefer, pelayanan behandle, pelayanan receiving dan delivery petikemas. Dalam melakukan sebuah pelayanan di pelabuhan tentunya akan saling berpengaruh dan berkaitan satu sama lain. Untuk itu lah penting untuk mengetahui pengaruh suatu kinerja tertentu agar dapat mengevaluasi kinerja yang telah terjadi serta dapat mempredikasi langkah apa yang harus dilakukan untuk menentukan perencanaan dan pengembangan serta menetapkan kebijakan - kebijakan.

Berdasarkan latar belakang tersebut, maka penulis mengambil judul Tugas Akhir yaitu "PENGARUH KINERJA PELAYANAN JASA BARANG TERHADAP PELAYANAN JASA KAPAL”. Berdasarkan Praktek Kerja Lapangan (PKL) pada PT Pelabuhan Cabang Tanjung Priok. Sedangkan fokus penulis dari penelitian ini adalah kinerja jasa barang (curah cair) terhadap kinerja jasa kapal (Effektive Time (ET)).

Berdasarkan masalah yang terjadi, maka penulis mengangkat beberapa masalah dalam penulisan Tugas Akhir ini, yaitu : a) bagaimana pengaruh pelayanan jasa barang terhadap pelayanan jasa kapal; b) mengidentifikasi variabel apa saja yang berpengaruh terhadap pelayanan jasa barang terhadap pelayanan jasa kapal; c) variabel apakah yang paling dominan atau berpengaruh pada pelayanan jasa kapal. Penulis memfokuskan masalah mengenai pengaruh pelayanan jasa barang terhadap pelayanan jasa kapal di Pelabuhan Cabang Tanjung Priok. Yang mana variabel yang 
penulis fokuskan yaitu variabel curah cair sebagai variabel independent atau variabel bebas sedangkan variabel Effective Time sebagai variabel dependen atau variabel terkait.

Berdasarkan identifikasi dan permasalahan diatas maka rumusan masalah dalam Tugas Akhir ini yang akan dibahas adalah "Apakah Kinerja Pelayanan Jasa Barang Curah Cair berpengaruh signifikan terhadap Kinerja Pelayanan Jasa Kapal Effective Time (ET)"

Adapun tujuan penulisan Tugas Akhir ini sebagai berikut; 1) untuk mengetahui seberapa besar pengaruh Kinerja Pelayanan Jasa Barang (Curah Cair) terhadap Kinerja Pelayanan Jasa Kapal (Effective Time); 2) untuk mengetahui tingkat keberhasilan pelayanan jasa barang (Curah Cair) dan pelayanan jasa kapal (Effective Time) yang telah di capai pada tahun 2018.

\section{B. METODE PENELITIAN}

Penelitian ini merupakan penelitian yang menggunakan rumus uji T. Melalui penelitian ini, penulis ingin mengetahui dan menganalisis pengaruh variabel independen yaitu curah cair sebagai variabel bebas, terhadap variabel dependennya yaitu Effective Time sebagai variabel terikatnya.

Ada dua variabel yang digunakan dalam penelitian ini, yaitu variabel bebas (independent variable) dan variabel terkait (dependent variable). Curah Cair (X) dijadikan variabel bebas karena variabel ini diduga dapat menjelaskan variabel lain atau memiliki pengaruh terhadap variabel lain. Variabel ini diukur dari kinerja pelayanan barang tahun 2018. Effective Time merupakan variabel terikat karena variabel ini diduga dapat dijelaskan dan dipengaruhi oleh variabel lain yaitu variabel bebas. Kedua variabel ini diteliti melalui kinerja pelayanan kapal tahun 2018.

Peneliti ini menggunakan metode kuantitatif dengan menggunakan rumus uji T. Pengolahan data sekunder dalam penelitian ini akan dilakukan dengan bantuan program Ms Exel. Penelitian ini menggunakan tingkat keyakinan 95\% yang berarti bahwa kemungkinan kesalahan dalam menolak hipotesis yang benar sebesar 5\%. Bagian metode berisi jenis metode atau jenis pendekatan yang digunakan, uraian data kualitatif dan/atau kuantitatif, prosedur dalam pengumpulan data, dan prosedur dalam analisis data.

\section{HASIL DAN PEMBAHASAN}

Kinerja pelayanan jasa kapal adalah untuk menilai realisasi pencapaian kinerja yang sudah dilakukan di PT Pelabuhan Cabang Tanjung Priok menggunakan Standar Dirjenla No.HK.103/2/18/DJPL - 16. Namun di dalam data Kinerja Operasi Tahun 2018 tidak tertulis angka standarisasinya pada pelayanan jasa kapal (Effective Time). Effective time sendiri adalah jumlah jam bagi satu kapal yang benar-benar digunakan untuk melakukan kegiatan bongkar muat barang. Dalam hal ini satuan yang adalah Jam. Dari grafik diatas dapat dilihat bahwa pencapaian realisasi tertinggi yaitu pada bulan Juli dengan angka 48,56. Sedangkan terendahnya pada bulan Oktober dengan angka 29,4.

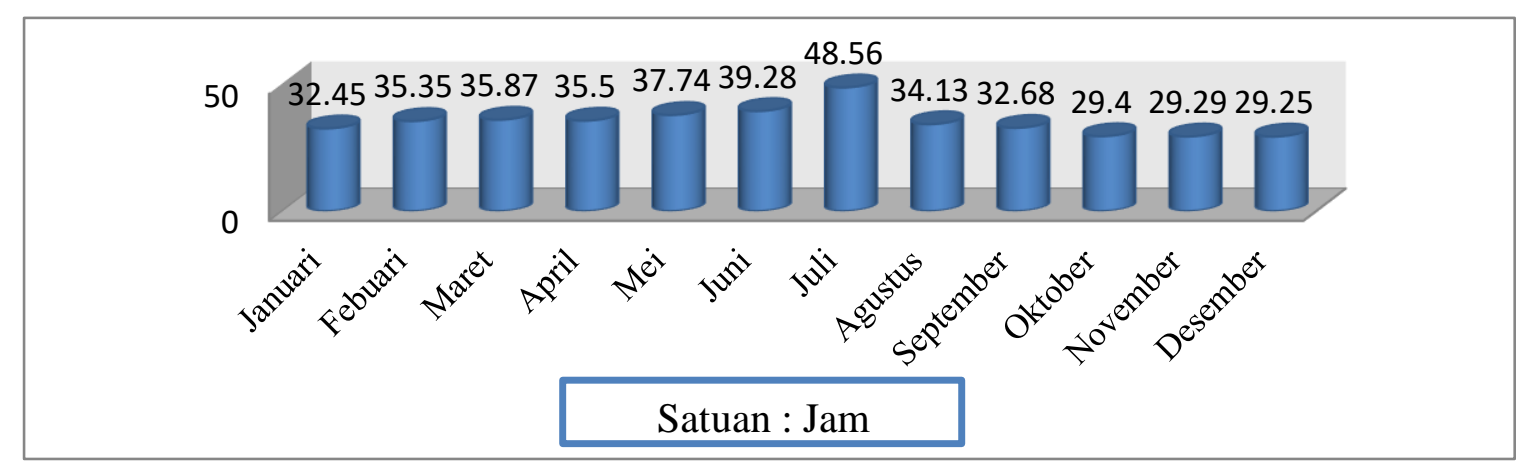

Gambar 1 Grafik Kinerja Effective Time Sumber: Kinerja Operasi Tahun 2018 


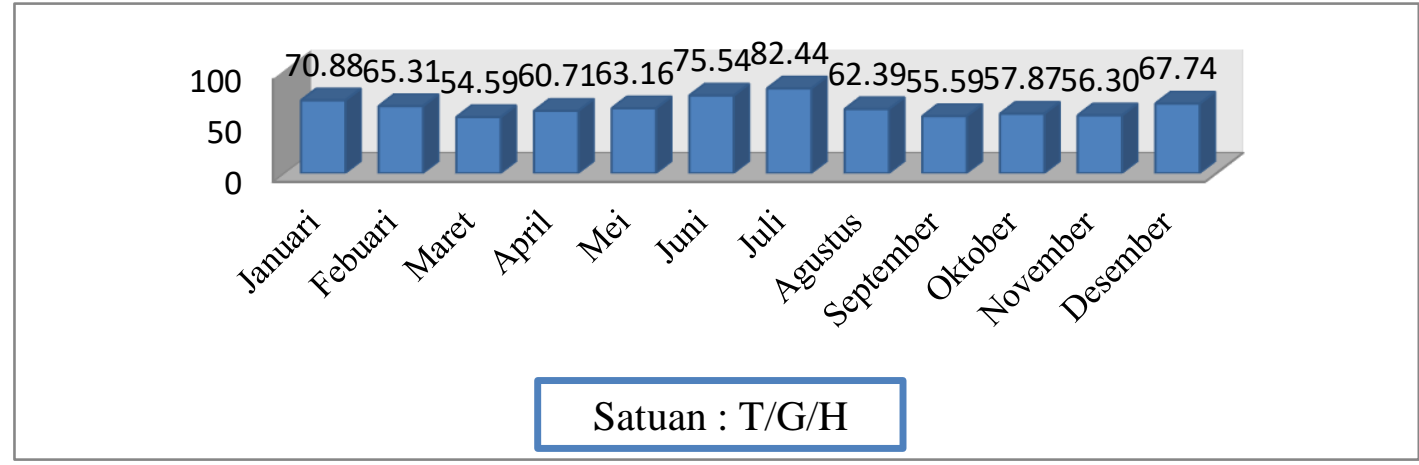

\section{Gambar 2 Grafik Kinerja Curah Cair Sumber: Kinerja Operasi Tahun 2018}

Kinerja pelayanan jasa barang (curah cair) menurut Standar Dirjenla No.HK.103/2/18/DJPL - 16 Curah Cair memiliki standar sebesar 150,00 dengan satuan $\mathrm{T} / \mathrm{G} / \mathrm{H}$. Dari grafik diatas dapat kita lihat bahwa dari realisasi pencapaian bulan Januari - Febuari angkanya tidak ada yang sampai mencapai angka 150,00. Pencapaian realisasi tertinggi yaitu pada bulan Juli yang angkanya mencapai 82,44 . Sedangkan pencapaian realisasi terendah yaitu pada bulan Maret sebesar 54,59. Dengan demikian pencapaian realisasi kinerja pelayanan barang pada curah cair tahun 2018 tidak mencapai target yang telah di tentukan oleh Standar Dirjenla No.HK.103/2/18/DJPL - 16 yaitu sebesar 150,00

Berdasarkan data yang terdapat di lapangan terkait dengan kinerja pelayanan jasa kapal dan kinerja pelayanan jasa barang (curah cair), maka hasil dari kegiatan tersebut adalah sebagai berikut :

1. Untuk Membuktikan atau mengasumsikan bahwa antara variabel curah cair $(\mathrm{X})$ dan variabel effective time (Y) mempunyai data yang normal dan dipilih secara acak.

2. Ha dan Ho dalam bentuk kalimat.

a. Ha: Terdapat hubungan yang positif dan signifikan antara variabel curah kering (X) dengan variabel effective time (Y).

b. Ho: Tidak terdapat hubungan yang positif dan signifikan variabel kapasitas curah cair $(\mathrm{X})$ dengan variabel effective time (Y).

3. Hipotesis statistiknya.
a. Ha: $r \neq 0$
b. Ho: $r=0$

4. Tabel untuk menghitung $\mathrm{T}$

Tabel 1 Data Olahan Variable $X$ dan Variable $Y$

\begin{tabular}{|c|c|c|c|c|c|c|c|c|}
\hline $\begin{array}{l}\text { No } \\
\text { Res }\end{array}$ & Bulan & $\begin{array}{c}\text { (X) } \\
\text { Curah } \\
\text { Cair }\end{array}$ & $\begin{array}{c}\text { (Y) } \\
\text { Effective } \\
\text { Time }\end{array}$ & $(\mathrm{X}-\overline{\mathrm{X}})=\mathbf{X}$ & $(\mathbf{Y}-\overline{\mathbf{Y}})=\mathbf{Y}$ & $\mathrm{X} 2$ & Y2 & $\mathbf{X Y}$ \\
\hline 1 & Januari & 70,88 & 32,45 & 6,50 & $-2,51$ & 42,3 & 6,3 & $-16,3$ \\
\hline 2 & Febuari & 65,31 & 35,35 & 0,93 & 0,39 & 0,9 & 0,2 & 0,4 \\
\hline 3 & Maret & 54,59 & 35,87 & $-9,79$ & 0,91 & 95,8 & 0,8 & $-8,9$ \\
\hline 4 & April & 60,71 & 35,50 & $-3,67$ & 0,54 & 13,4 & 0,3 & $-2,0$ \\
\hline 5 & Mei & 63,16 & 37,74 & $-1,22$ & 2,78 & 1,5 & 7,7 & $-3,4$ \\
\hline 6 & Juni & 75,54 & 39,28 & 11,16 & 4,32 & 124,6 & 18,7 & 48,2 \\
\hline 7 & Juli & 82,44 & 48,56 & 18,06 & 13,60 & 326,3 & 185,0 & 245,7 \\
\hline 8 & Agustus & 62,39 & 34,13 & $-1,99$ & $-0,83$ & 3,9 & 0,7 & 1,6 \\
\hline 9 & September & 55,59 & 32,68 & $-8,79$ & $-2,28$ & 77,2 & 5,2 & 20,0 \\
\hline 10 & Oktober & 57,87 & 29,40 & $-6,51$ & $-5,56$ & 42,3 & 30,9 & 36,2 \\
\hline 11 & November & 56,30 & 29,29 & $-8,08$ & $-5,67$ & 65,2 & 32,1 & 45,8 \\
\hline 12 & Desember & 67,74 & 29,25 & 3,36 & $-5,71$ & 11,3 & 32,6 & $-19,2$ \\
\hline \multicolumn{2}{|c|}{ Jumlah } & $\begin{array}{l}\sum \mathbf{X}= \\
772,52\end{array}$ & $\begin{array}{l}\sum \mathbf{Y}= \\
419,5\end{array}$ & 0,00 & 0,00 & $\begin{array}{c}\sum \mathbf{X}^{2}= \\
804,8\end{array}$ & $\begin{array}{c}\sum \mathbf{Y}^{2}= \\
320,5\end{array}$ & $\begin{array}{r}\sum \mathbf{X Y}= \\
348,1\end{array}$ \\
\hline \multicolumn{2}{|c|}{ Rata-rata } & $\begin{array}{l}\overline{\mathbf{X}}= \\
64,38 \\
\end{array}$ & $\overline{\mathbf{Y}}=34,96$ & & & & & \\
\hline
\end{tabular}


Tabel diatas merupakan hasil data yang telah diolah penulis yang mana data tersebut akan penulis gunakan untuk menghitung menggunakan rumus uji $\mathrm{T}$.

1. Rumus $r_{x y}$ hitung

$$
\begin{aligned}
& r_{x y}=\frac{\sum x y}{\sqrt{\left(\sum X^{2}\right)\left(\sum Y^{2}\right)}} \\
& =66986551,4 \\
& =\frac{348,1}{\sqrt{804,8 \times 320,5}} \\
& =\frac{348,1}{507,87}=0,685
\end{aligned}
$$

2. Rumus thitung:

$$
\begin{aligned}
\mathrm{t}_{\text {hitung }} & =\mathrm{r} \sqrt{\frac{\mathrm{n}-2}{1-\mathrm{r}^{2}}} \\
& =0,685 \sqrt{\frac{12-2}{1-0,685^{2}}} \\
& =0,685 \sqrt{10 / 0,53=2,97}
\end{aligned}
$$

3. Menetapkan taraf signifikansi sebesar 0,05

4. Untuk menentukan kriteria pengujian signifikansi korelasi yaitu:

Ha: Signifikan

Ho: Tidak Signifikan

5. Jika $-\mathrm{t}_{\text {tabe }} \mathrm{I} \leq \mathrm{t}_{\text {hitung }} \leq \mathrm{t}_{\text {tabel }}$, maka $\mathrm{H}_{\mathrm{o}}$ diterima dan $\mathrm{H}_{\mathrm{a}}$ ditolak artinya korelasinya tidak signifikan atau tidak ada pengaruh yang signifikan.

Jika $-\mathrm{t}_{\text {tabe }}<<\mathrm{t}_{\text {hitung }}<\mathrm{t}_{\text {tabel }}$, maka $\mathrm{H}_{\mathrm{o}}$ ditolak dan $\mathrm{H}_{\mathrm{a}}$ diterima artinya korelasinya signifikan atau ada pengaruh yang signifikan.

6. $\quad \mathrm{Dk}=\mathrm{n}-2$

$=12-2=10$

Dengan taraf signifikansi sebesar 0,05 maka dari tabel $\mathrm{t}$ di dapat $\mathrm{t}_{\text {tabel }}=2,228$

7. Ternyata $-2,228>2,97>2,228$ atau $-t_{\text {tabe }}>>t_{\text {hitung }}>t_{\text {tabel }}$, sehingga $\mathrm{H}_{\mathrm{a}}$ diterima dan $\mathrm{H}_{\mathrm{o}}$ ditolak. Artinyaa terdapat korelasi yang signifikan atau ada pengaruh yang signifikan antara variabel curah cair $(\mathrm{X})$ terhadap variabel effective time $(\mathrm{Y})$

8. Kesimpulannya: Hubungan antara variabel curah cair $(\mathrm{X})$ dengan variabel effective time $(\mathrm{Y})$ ternyata positif dan signifikan.

9. Maka besarnya pengaruh sumbangan variabel curah cair $(\mathrm{X})$ terhadap variabel effective time $(\mathrm{Y})$ adalah: $0,685^{2} \times$ $100 \%=46 \%$. Sedangkan sisanya yang lain ditentukan oleh variabel lain.

\section{KESIMPULAN}

1. Berdasarkan hasil perhitungan diatas dapat disimpulkan bahwa:
a. $\quad$ Nilai hitung sebesar $=0,685$
b. Nilai hitung sebesar $=2,97$
c. $\quad$ Nilai tabel sebesar $=2,228$
d. Interpretasi nilai tabel $=-2,228>2,97>2,228$ atau - ttabe $1>$ thitung $>$ ttabel, sehingga Ha diterima dan Ho ditolak. Artinyaa terdapat korelasi yang signifikan atau ada pengaruh yang signifikan antara variabel curah cair $(\mathrm{X})$ terhadap variabel effective time $(\mathrm{Y})$.
e. Hubungan antara variabel curah cair $(\mathrm{X})$ dengan variabel effective time (Y) ternyata positif dan signifikan.
f. Maka besarnya pengaruh sumbangan variabel curah cair $(\mathrm{X})$ terhadap variabel effective time (Y) adalah: $0,6852 \times 100 \%=46 \%$. Sedangkan sisanya yang lain ditentukan oleh variabel lain.

2. Pencapai realisasi pelayanan jasa barang pada curah cair pada tahun 2018 dari bulan Januari - Desember tidak ada yang mencapai target standarisasi 150,00. Sedangkan pencapaian realisasi pelayanan jasa kapal pada effective time tidak terdapat angka standarisasinya. 


\section{E. SARAN}

Berdasarkan uraian diatas, adapun saran yang dapat disampaikan oleh penulis adalah sebagai berikut:

1. Dikarenakan ada beberapa realisasi yang masih belum mencapai target oleh karena itu sebaiknya PT Pelabuhan Indonesia II meningkatkan pelayanannya. Baik itu dari segi administrasi maupun dari peralatan bongkar muat dan fasilitas lainnya.

\section{F. DAFTAR PUSTAKA}

Anonim, Pengertian Kinerja Pelayanann. Repository.radenintan.ac.id \{Diakses 27 Juli 2019\}

Anonim, Pengertian Muatan. www.maritimeworld.web.id \{28 Juli 2019\}

Anonim, Pengertian Pengaruh. Digilibi.unila.ac.id \{28 Juli 2019\}

Begum, Amaliah. 2009. Pengaruh Penganggaran Partisipatif. Fakultas Ekonomi, Universitas Indonesia. lib.ui.ac.id \{ 23 Juli 2019\}

Drs. Riyadi, DKK. 2015. Buku Panduan Penyusunan Tugas Akhir. Jakarta: Universitas Negeri Jakarta.

Muhammad, Ferdian Fachri. 2018. Evaluasi Target Realisasi Jumlah Kedatangan Kapal Terminal Domestik Di PT. Indonesia Kendaraan Terminal. Fakultas Teknik. Universitas Negeri Jakarta.

Wibowo, Harmaini. 2010. Analisis Faktor - Faktor Yang Mempengaruhi Waktu Tunggu Kapal Di Pelabuhan Tanjung Emas semarang. https://core.ac.uk \{21 Juli 2019\}

Surat Keputusan General Manager Cabang Pelabuhan Tanjung Priok No: HK.01/18/4/1/D4.1/GM/C.TPK-18 tentang Standar Pelayanan Terminal Petikemas Cabang Pelabuhan Tanjung Priok. 2018. Jakarta: PT Pelabuhan Indonesia II (Persero) Cabang Tanjung Priok. Usman, Husaini, Akbar Setiady, R. Purnomo. 1995. Pengantar Statistika. 